\title{
THE EFFECT OF CRIMINAL JUDGMENTS ON LICENSE REVOCATION PROCEEDINGS
}

Governmental licensing of private activities coupled with the safeguard of revocation now establishes and maintains standards of conduct for nearly all trades and professions, as well as for many non-commercial activities. ${ }^{1}$ The same conduct which gives rise to license revocation proceedings may also subject the licensee to criminal prosecution.

It is often urged that a criminal judgment resulting in acquittal should operate as res judicata in any subsequent revocation proceedings based on the same conduct. ${ }^{2}$ Since one sovereignty is punishing a party for the same conduct in two proceedings, the doctrine of res judicata initially seems applicable. It has been said:

[T]he basis of the doctrine of [res judicata] is the policy and necessity of preventing continuous litigation over the same matter to the great vexation of the parties and the obstruction of the judicial machinery, and not the assumption that the judgment is a legally or ethically correct determination of the rights of the parties. ${ }^{3}$

Furthermore, the licensee's interest, although often characterized as a "mere privilege," is of considerable importance, and revocation has a penalizing effect. Increased protection under the due process clause is being given to the right to work at one's chosen trade or profession. ${ }^{4}$ Because the effect given a criminal

${ }^{1}$ The index to the Consolidated Laws of New York (McKinney, 1955), Book 68, Master Index D-L, 880-890, lists over three hundred occupations which require licenses. For a general discussion of licensing, its importance and extent, consult Freund, Licensing, 9 Encyc. Soc. Sci. 447-51 (1933); Chapman, Indiana Licensing Law 5-9 (1953); Parsons, The Use of the Licensing Power by the City of Chicago c. 9 (1952).

${ }^{2}$ See, e.g., Silver v. McCamey, 221 F. $2 d 873$ (App. D.C., 1955); Cornell v. Reilly, 127 Cal. App. 2d 178, 273 P. 2d 572 (1954).

32 Freeman, Judgments $\S 641$, at 1349 (5th ed., 1925). Consult generally Comm'r v. Sunnen, 333 U.S. 591, 597 (1948); von Moschzisker, Res Judicata, 38 Yale L.J. 299 (1929).

\footnotetext{
4 In a recent case involving the revocation of a physician's license, Justice Douglas stated in dissent: "The right to work, I had assumed, was the most precious liberty that man possesses. Man has indeed as much right to work as he has to live, to be free, to own property.... It does many men little good to stay alive and free and propertied, if they cannot work. To work means to eat. It also means to live. For many it would be better to work in jail, than to sit idle on the curb." Barsky v. Board of Regents, 347 U.S. 442, 472 (1954). Accord: Leakey v. Ga. Real Estate Commission, 80 Ga. App. 272, 55 S.E. 2 d 818 (1949).

There is nevertheless a controversy in administrative law as to whether a license is a mere privilege revocable at will, Wallace v. Mayor of Reno, 27 Nev. 71, 73 Pac. 528 (1903), Nulter v. State Road Commission, 119 W. Va. 312, 193 S.E. 549 (1937), or a right which cannot be deprived without due process, Leakey v. Ga. Real Estate Comm'n, $80 \mathrm{Ga}$. App. 272, 55 S.E. 2d 818 (1949) (real estate dealer's license); Carroll v. Cal. Horse Racing Board, 16 Cal. 2d 164, 105 P. 2d 110 (1940) (horse racing license). The latter position is reflected in the Administrative Procedure Act, 60 Stat. 237 (1946), 5 U.S.C.A. $\$ \$ 1001(\mathrm{e}), 1008$ (1947). See also Standard Airlines v. CAB, 177 F. 2d 18 (App. D.C., 1949). The commentators also favor this view: Davis, Administrative Law 250 (1951); Sears, Licenses and Procedural Due Process, Brochure on Administrative Law 7 (1943).
} 
judgment in a subsequent license revocation hearing has important consequences for both efficient judicial administration and personal rights, it would seem worth while to examine whether a workable and fair rule concerning the treatment of criminal judgments in such a situation can be devised.

Usually a criminal acquittal is not accorded res judicata effect upon a subsequent hearing to revoke a license although the offense in both proceedings was based on the same conduct. In a typical case, Silver v. McCamey, ${ }^{5}$ a taxicab driver's license was revoked because of an alleged sexual assault and armed robbery. The driver was acquitted of the assault charge at a criminal trial. The court of appeals, while reversing the revocation on other grounds, ${ }^{6}$ was careful to state that the acquittal would not operate as res judicata and thus bar revocation for the same conduct. ${ }^{7}$ Initially, such a categorical view appears questionable. Although the defendant had successfully defended his innocence of a criminal charge, he might be barred on the same charge by another arm of the government from pursuing his occupation.

Many courts have failed to give satisfactory explanations for this refusal to follow the policy of res judicata in subsequent license hearings. Several courts, for example, express the view that res judicata is inapplicable because the criminal prosecutor and the licensing agency are different parties. ${ }^{8}$ The more widely accepted view, however, is that various agencies of the same government are in privity with each other for purposes of res judicata. ${ }^{9}$ Other courts have explained that res judicata is unavailable because of the fundamentally differing purposes of the criminal prosecution and revocation proceedings. ${ }^{10}$

6 221 F. 2d 873 (App. D.C., 1955).

-The taxicab driver had been separately indicted for rape on two different dates. Trial for the second alleged rape resulted in acquittal. After indictment (but before trial) for the first alleged rape, the Board of Revocation and Review of Hackers' Identification Licenses held a hearing on the rape charge pending trial which resulted in permanent revocation of the license. The Court of Appeals held that pending the second trial the Board had power only to suspend the license, since revocation proceedings might cause disclosure of defenses intended for the criminal trial.

7t should be noted that there were other facts unfavorable to the licensee. A bayonet and pistol cartridges were found in the taxicab at the time of arrest. In this regard the court remarked, "Misconduct need not amount to rape in order to show that a man is unfit to operate a taxicab." Ibid., at 875.

${ }^{8}$ State v. Rowlett, 138 Fla. 330, 190 So. 59 (1939); Barach's Case, 279 Pa. 89, 123 Atl. 727 (1924).

' Sunshine Anthracite Coal Co. v. Adkins, 310 U.S. 381, 402 (1940); United States v. Willard Tablet Co., 141 F. $2 d 141$ (C.A. 7th, 1944); George H. Lee Co. v. FTC, 113 F. 2d 583, 585 (C.A. 8th, 1940). On the other hand, if two different governing entities, i.e., separate states or the nation and a state, instigate the separate proceedings, res judicata then can be rightfully rejected because of the difference in parties. Garsson v. Wallin, 279 App. Div. 1111, 113 N.Y.S. 2d 1 (3d Dep't, 1952), aff'd 304 N.Y. 702, 107 N.E. 2d 604 (1952); Barach's Case, 279 Pa. 89, 123 Atl. 727 (1924). Consult von Moschzisker, Res Judicata, 38 Yale I.J. 299, 302 (1929).

${ }^{10}$ E.g., State v. Lewis, 164 Wis. 363, 159 N.W. 746 (1916). 
[Revocation] [p]roceedings ... are not in their nature an effort to further punish one who may already have been punished for the same offense, but are the rightful exercise of the power of the state to protect its citizens from physicians of bad character."1

Such a distinction is difficult to acknowledge because criminal punishment is also instituted at least partially for the protection of society. Moreover, deprivation of such valuable interests as the right to engage in a chosen trade, profession, or business, or to operate an automobile is as much a punishment to the accused as the deprivation of money by fines or even incarceration. ${ }^{12}$

A more concrete objection to applying res judicata is that the two proceedings differ in amount of proof required..$^{13}$ For example, in Commonwealth $v$. Funk, ${ }^{14}$ the state sought to revoke an automobile operator's permit for violation of the motor vehicle laws. The licensee had previously been acquitted of driving while intoxicated-the substance of the accusation against him in the revocation hearing. In holding that the result of the criminal prosecution did not bar a subsequent administrative proceeding based on the same set of facts, the court said:

In criminal proceedings the guilt of the accused must be established beyond reasonable doubt. In a civil proceeding to revoke a license it is sufficient if the offense be established by a preponderance of evidence..$^{15}$

The objection to applying res judicata because of differing burdens of proof has been rejected, however, in a number of federal cases involving statutory forfeiture actions following criminal acquittals. In the leading case of Coffey v. United States ${ }^{16}$ the Supreme Court decided that a judgment acquitting the defendant of a tax fraud was conclusive of his innocence in a statutory forfeiture action to confiscate the distillery equipment and apple brandy used in committing the fraud. The Court rejected the argument based upon the difference in burdens of proof and held that "a subsequent trial of the civil suit amount[ed] to substantially the same thing, with a difference only in the consequences following a judgment adverse to the claimant."17 The Coffey case, however, has been severely criticized ${ }^{18}$ or distinguished away in subsequent forfeiture cases ${ }^{19}$

11 Ibid., at 366 and 747. Similar language is found in Cornell v. Reilly, 127 Cal. App. 2d 178, 184, 273 P. 2d 572, 576 (1954); Barach's Case, 279 Pa. 89, 95, 123 Atl. 727, 729 (1924); In the Matter of Smith, 10 Wend. (N.Y.) 449,459 (1833).

12 See note 4 supra.

${ }^{13}$ Silver v. McCamey, 221 F. 2d 873 (App. D.C., 1955); Commonwealth v. Funk, 323 Pa. 390, 400, 186 Atl. 65, 70 (1936); Tapley v. Abbott, 111 Cal. App. 397, 295 Pac. 911 (1931).

$14323 \mathrm{~Pa} .390,186 \mathrm{Atl} .65$ (1936). A dictum in this case raises the collateral problem of the evidentiary use of a prior criminal judgment, which is discussed at pp. 342-43 infra.

${ }^{15}$ Ibid., at 400 and 70.

16116 U.S. 436 (1886).

${ }^{17}$ Ibid., at 443 . Statutory forfeiture suits are actions in rem to confiscate property used in activity forbidden by statute.

${ }^{18}$ Justice Clark has observed that the Coffey case "has received a distinctly unfavorable press." United States v. One Dodge Sedan, 113 F. 2d 552, 553 (C.A. 3d, 1940) (held, that acquittal of husband did not bar forfeiture of the auto allegedly used in the crime, since the wife 
and has been repudiated in a similar body of cases involving tax penalty damages. ${ }^{20}$ In light of the deterioration of the Coffey doctrine, most courts today would probably recognize the difference in burdens of proof as a valid reason for not applying res judicata in license revocation proceedings.

An inherent difficulty in applying res judicata as a general principle to license cases lies in the fact that different issues may arise in the criminal and revocation proceedings. Revocation proceedings may scrutinize the licensee's behavior for conduct which denotes technical unfitness, breach of professional ethics, ${ }^{2 \mathrm{i}}$ or moral turpitude..$^{22}$ Criminal trials inquire only into whether the defendant committed a specified crime on a particular occasion. For example, it was held in the early New York case of In the Matter of Smith ${ }^{23}$ that a physician's state medical license could be revoked for professional misconduct arising from the performance of an alleged abortion although the physician had been acquitted of abortion at a criminal trial. The acquittal resulted, however, from a finding that the child in the abortion had not been "quick" so that the offense charged was not punishable under existing New York criminal law. ${ }^{24}$ The failure to accomplish a

of the acquitted held legal title to the auto). Consult also Multiple Punishment Under the Double Jeopardy Rule, 31 Col. L. Rev. 291 (1931).

${ }^{19}$ A recent case following the Coffey case is United States v. One De Soto Sedan, 85 F. Supp. 245 (E.D. N.C., 1949), aff'd 180 F. 2d 583 (C.A. 4th, 1950). Contra: United States v. Physic, 175 F. 2d 338 (C.A. 2d, 1949) (acquittal for unlawful transportation of heroin held no bar to forfeiture of automobile which was allegedly used in the transportation); People v. One 1950 Cadillac 2-Door Club Coupe, 133 Cal. App. 2d 311, 284 P. $2 d 118$ (1955); State v. Dubose, 152 Fla. 304, 11 So. 2d 477 (1943).

Since forfeiture is regarded in these cases as a cumulative punishment for a criminal offense there is logical justification in not punishing a person previously acquitted of the offense. One case considering whether a criminal acquittal estops a license revocation, Steele v. State Road Comm'n, 116 W.Va. 227, 179 S.E. 810 (1935), has stated by dictum that the Coffey case did not control because it was "the minority rule." Ibid., at 229 and 811 . The court relied on Stone v. United States, 167 U.S. 178 (1897). The crime with which the defendant was charged and acquitted in the Stone case was for "cutting or removal of timber from the lands of the United States." Ibid., at 179. The federal government then sued the defendant for conversion of the timber, claiming that the Coffey case did not apply to a civil action brought by the government in its capacity as a property owner. The Supreme Court accepted this distinction, emphasizing that the penal purpose of the forfeiture suit in the Coffey case distinguished it from the instant case. Ibid., at 186.

${ }^{20}$ Since Helvering v. Mitchell, 303 U.S. 391 (1938), it has been settled that acquittal of fraudulently evading the Internal Revenue Code does not bar a suit for penalty damages for the same alleged tax evasion.

${ }^{21}$ See, e.g., 5 Ariz. Code Ann. (1939) $\S 63-605$, authorizing revocation of a certified public accountant's license if he is "guilty of any ... default discreditable to his profession."

22 See, e.g., 11 Ind. Stat. Ann. (Burns, 1951) Pt. 1, $\$ 63-1120$, authorizing revocation of the license of any pharmacist who is "guilty of . . gross immorality. ..."

${ }^{23} 10$ Wend. (N.Y.) 449 (1833). The case is respectable authority in spite of its age. Consult Effect of Acquittal or Dismissal in Criminal Prosecution To Bar Revocation of License of Physician or Disbarment of Attorney, 123 A.L.R. 779, 785 (1939).

24 See also, In re Lincoln, 102 Cal. App. 733, 283 Pac. 965 (1930) where an attorney was disbarred for acts involved in obtaining money by false pretenses. He had previously been 
criminal result should not preclude revocation for the ineffective attempt. Other acquittals may rest on a finding of insanity or consent. A physician indicted for the rape of a hospital patient but acquitted for reason of consent certainly should not be protected from a license revocation based upon breach of professional ethics or medical malpractice.

But in some situations the offense charged in the revocation proceedings will be exactly the same as the previous criminal charge. ${ }^{25} \mathrm{In}$ Silver $v$. McCamey ${ }_{2}^{26}$ for example, the charge in the revocation proceeding was taken verbatim from the indictment of which the licensee had been acquitted. Even so, the issues of the two proceedings were not necessarily identical since the statute authorized revocation merely when administrative officials found such action desirable. ${ }^{27}$ The more difficult problem is presented when the two proceedings, as in Commonzealth v. Funk, ${ }^{28}$ are based upon the same charges and the issues are necessarily identical. Here, the administrative official was empowered to suspend a driver's permit whenever he found upon sufficient evidence that such person had committed any violation of the motor vehicle laws of the state. ${ }^{29}$ The official was not authorized to revoke upon other more general grounds such as moral turpitude or professional misconduct. Therefore, with an identity of issues in both criminal and revocation proceedings, only the difference in burdens of proof could preclude the operation of res judicata. As a practical matter, due to the differences in proof required, some unfairness might result in applying res judicata to license revocations even where the issues are identical to those in prior criminal prosecutions. Whereas persons who are not prosecuted for the commission of crimes might be required to forfeit their licenses, others in similar circumstances who were acquitted of the same offense would be immune from revocation.

The discussion thus far has failed to take account of what is perhaps the most significant practical consideration: If the doctrine of res judicata did exist within a jurisdiction, it is doubtful that more than a few cases would come within its ambit. License authorities would tend to form their accusations to avoid the

acquitted of the crime of obtaining money by false pretenses. The disbarment authorities indicated that the attorney's acts constituted professional and moral misconduct, regardless of their nature as part of a criminal offense.

${ }^{25}$ State v. Driskell, 139 Fla. 49, 190 So. 461 (1939) (medical license revoked for professional misconduct in performing an abortion - the licensee was previoulsy acquitted of the crime of performing the abortion); State v. Lewis, 164 Wis. 363, 159 N.W. 746 (1916); see In re Doe 95 F. 2d 386 (C.A. 2d, 1938). Contra: People v. John, 212 Ill. 615, 72 N.E. 789 (1904) (acquittal of attorney charged with embezzlement held conclusive of his innocence in a subsequent proceeding to disbar for embezzlement); see In re Patlak, 368 Ill. 547, 15 N.E. $2 \mathrm{~d} 309$ (1938).

${ }^{26} 221$ F. 2 d 873 (App. D.C., 1955), discussed in text at p. 337, supra.

${ }^{27}$ D.C. Code (1951) \& 47-2345.

${ }^{28} 323 \mathrm{~Pa} .390,185$ Atl. 65 (1936).

${ }^{29}$ Pa. L. (1929) No. 403, Art. VI, § 615(b), as amended, 75 Pa. Stat. Ann. (Purdon, 1953) $\S 192(\mathrm{~b})$. 
conclusive effect of a prior acquittal. In the Silver case, for example, the license board could have avoided the question of the res judicata effect of the rape acquittal by charging the hacker with indecent conduct or exposure. An analogous practice exists in the field of criminal law wherein prosecutors avoid the rule against double jeopardy by splitting the offense into several charges and prosecuting for each. ${ }^{30}$ Indeed, the usual revocation proceeding is far more adaptable to this practice than are criminal prosecutions because grounds for revocation such as professional misconduct allow more flexibility than a list of specific crimes defined by statute. Even where grounds for revocation are limited to statutory violations, as in the Funk case, the practice of framing different accusations should be no more difficult than in criminal prosecutions.

It should be added that all the foregoing reasons for not applying res judicata pertain equally well to the case of a petition for reinstatement of a license when criminal acquittal follows revocation. ${ }^{31}$

Where the prior criminal prosecution produces a conviction rather than an acquittal, the differing-burdens-of-proof argument is not available against applying res judicata in the license revocation proceedings. The revocation authorities will not be tempted to phrase the charges to avoid deliberately a conclusive effect of the criminal judgment. But the statutory grounds for revocation will determine the use of a prior conviction. ${ }^{32}$ Revocation on this ground may be

so "[N]ot only may prosecutors use one act to fit several separate counts of the same indictment; they may frame successive independent indictments from the variety of offense schemes applicable to the particular facts." Kirchheimer, The Act, The Offense and Double Jeopardy, 58 Yale L.J. 513, 514 (1949). Illustrative cases are collected in Boyer, The Riddle of Double Jeopardy in Wisconsin: The Defendant's View, 1954 Wis. L. Rev. 395, 405.

${ }^{31}$ In Qualtop Beverages v. McCampbell, 31 F. $2 d 260$ (C.A. 2d, 1929) reinstatement was denied without explicit comment, however, on the retroactive conclusive effect of a criminal acquittal. The case involved rather the question of whether the evidence of acquittal was unfairly rejected at proceedings to review the revocation. The court held that the review could merely decide whether the revocation proceeding was arbitrary or based on an erroneous view of the law.

The negative implication is that the acquittal would not have a conclusive effect on reinstatement. Of course, a license revocation will not operate as res judicata upon a subsequent prosecution. Revocation, while nominally for a criminal offense, might have been based upon non-criminal grounds, thus creating different issues in the two proceedings. Moreover, the defendant would be denied the protection of the reasonable doubt rule in the criminal trial because the revocation was based upon a mere preponderance of evidence.

Likewise, if a license is not revoked in a hearing prior to a criminal trial the doctrine of res judicata should not be applied. The doctrine would have the undesirable effect of preempting criminal prosecution. Also the failure to revoke may mean only that, despite a finding of guilt, the agency used its discretionary authority not to revoke, or that the offense did not come within any of the prescribed grounds for revocation.

32 The following excerpt is representative of statutory authority for license revocation upon criminal conviction: Colo. Rev. Stat. (1953) c. 62, Arts. 6-16 (Revocation of Fur Dealer's License): "(1) Any violation of the game and fish laws, or of any rule or regulation of the [Game and Fish] commission shall be grounds for the suspension of any license. ... (2) Upon conviction of such violation in any court of this state, any license shall be revoked by the commission. . . ."

The propriety of revoking a license for criminal conduct prior to any criminal trial was considered in Ex Parte Wall, 107 U.S. 265 (1882). In that case an attorney was summarily 
discretionary with the license authorities. ${ }^{33}$ Where conviction is not a statutory basis for revocation, the conviction will have no conclusive effect on the license proceedings.

While the courts generally have refused to give prior criminal judgments res judicata effects in license revocation hearings, several cases $^{34}$ and commentators $^{35}$ favor admitting the judgment into evidence. In Commonwealth v. Funk, for example, the court stated:

[A] criminal prosecution does not bar a subsequent ... administrative proceeding based on the same set of facts, nor does a judgment rendered therein have any probative effect beyond its rendition. ${ }^{36}$ [Emphasis supplied.]

Where the judgment was acquittal, however, neither the cases nor the commentators reveal the use to which the fact of rendition is to be put. Assuming the

disbarred by a United States District Judge because of the attorney's instigation of and participation in the lynching of a federal prisoner. The court upheld the disbarment, ruling that disbarment before criminal trial is permissible in matters in which the attorney "is guilty of gross misconduct in his profession, or of acts which, though not done in his professional capacity, gravely affect his character as an attorney." Ibid., at 280. Accord: In re Wills, $293 \mathrm{Ky} .201$, 168 S.W. 2 d 730 (1943); In re Young, 77 Mont. 332, 250 Pac. 957 (1926). Contra: In re Chappell, 33 N.E. 2d 393 (Ohio App., 1938).

When revocation proceedings are held during pendency of a criminal trial for the same offense two problems are raised. First, does the unfairness involved in compelling the licensee to reveal possible defenses before trial amount to a denial of due process? See Silver v. McCamey, 221 F. 2d 873 (App. D.C., 1955). Second, is the indictment admissible as evidence in the license proceedings? Refer to discussion of conviction as evidence at text pp. 342-43.

${ }^{33}$ Consult, e.g., 20 Tex. Civ. Stat. Ann. (Vernon, 1951) Art. 7458: "The right to practice veterinary medicine in this State may be revoked by any court of competent jurisdiction upon proof of the violation of the law in any regard thereto or for any cause for which the State Board of Veterinary Medical Examiners is authorized by law to refuse to admit to its examinations. ..."; Art. 7459: "The State Board of Veterinary Medical Examiners may refuse to admit to its examinations or to issue the certificate provided for by this law for any of the following causes: The presentation to the Board of any license, certificate or diploma which was illegally or fraudulently obtained, or when fraud or deception has been practiced in passing the examination; conviction of a crime of the grade of felony, or one which involves moral turpitude; other grossiy unprofessional or dishonorable conduct of a character likely to deceive or defraud the public; or for habits of intemperance or drug addiction calculated to endanger the lives of patients" (italics added).

34 Commonwealth v. Funk, 323 Pa. 390, 186 Atl. 65 (1936). Accord: In re O'Brien, 95 Vt. 167, 113 Atl. 527 (1921). But cf. Qualtop Beverages v. McCampbell, 31 F. 2d 260 (C.A. 2d, 1929).

${ }^{35}$ Dean Wigmore argued, "But may not a judgment in a prior cause be at least admissible as evidence when the issue there investigated was substantially the same as the present one? ... Is not the finding of a judge, or the verdict of a jury, based on at least as thorough an inquiry as ... other reports and certificates? Has it not some value as evidence, even though not conclusive?" IV Wigmore, Evidence § 1346a, at 671 (3d ed., 1940). Illustrative cases and more specific discussion are found at V Wigmore, Evidence $\$ 1671$ a (3d ed., 1940). Accord: 1 Greenleaf, Evidence $\$ 537$ (16th ed., 1899); Starkie, Evidence *361 (9th Am. from 4th Eng. ed., 1869). But compare Judgment of Conviction-Effect on a Civil Case as Res Judicata or as Evidence, 27 IIl. L. Rev. 195 (1932), where it is suggested that the probative value of the conviction is too conjectural to warrant its admission as evidence.

${ }^{36} 323 \mathrm{~Pa} .390,400,186$ Atl. 65, 70 (1936). 
evidence is competent, it surely can be indicative of nothing more than the fact that twelve men, judging the same facts by a different standard, decided that the defendant was not guilty of a particular crime. When the fact-finders are satisfied as to the licensee's guilt or misbehavior from other evidence, are they to disregard the fact of rendition, or should they change their finding as a result of it? Either choice involves a speculation as to what the jury would have done if not restricted by the reasonable doubt rule. This task is in its nature impossible. The evidence has no relevance beyond that which the fact-finders choose to give it. On the other hand, where the prior judgment was a conviction, the fact of rendition may have a legitimate evidentiary use. Where not in itself a ground for revocation, the conviction may be relevant to such statutory grounds for revocation as professional misconduct or commission of a crime involving moral turpitude. ${ }^{37}$

In conclusion, prior criminal acquittals have a limited relevance in license revocation proceedings, but convictions have considerably more relevance. Nevertheless, in both situations there are theoretical and practical objections to the use of res judicata which override its salutary policy of diminishing litigation. Convictions may be relevant as evidence, but admitting evidence of the rendition where the licensee has been acquitted has no utility beyond allowing the fact-finders a discretionary power to give the acquittal a conclusive effect. The latter practice would lead to uneven and uncertain-and hence undesirable -results.

${ }^{27}$ Refer to note 33 supra.

\section{THE ROLE OF THE JUDICIAL SALE IN PREVENTING UNECONOMICAL PARCELLATION OF INHERITED LAND}

For over one hundred years it has been the general rule in the United States that intestate property descends equally to the decedent's children, subject to the rights of the surviving spouse. ${ }^{1}$ Developed largely in response to democratic ideals of equality ${ }^{2}$ and dignity of ownership, ${ }^{3}$ partible inheritance has been increasingly criticized in modern times. Proponents of land reform claim that parcellation, especially of agricultural land, ${ }^{4}$ among several heirs through suc-

${ }^{1}$ Consult, for a brief survey, Wypyski, The Law of Inheritance (Legal Almanac Series, 1953).

2 See Rheinstein, Cases on Decedents' Estates 28 (2d ed., 1955).

3 Sayre, Recent Ideologies in the Law of Succession to Property, 32 Ill. L. Rev. 691, 693 (1938). For discussions on the beginnings of partible inheritance in the United States consult Haskins, The Beginnings of Partible Inheritance in the American Colonies, 51 Yale L. J. 1280 (1942); Morris, Primogeniture and Entailed Estates in America, 27 Col. L. Rev. 24 (1927).

- It has been estimated that five out of six farmers die intestate. Johnson and Barlowe, Land Problems and Policies 287 (1954). 